DOI https://doi.org/10.18551/rjoas.2021-01.23

\title{
THE EFFECT OF INTERNAL CONTROL AND INDIVIDUAL MORALITY ON FRAUD PREVENTION IN PT. REGIONAL DEVELOPMENT BANK OF SOUTHEAST SULAWESI
}

\author{
Mustafa Santiadji* \\ University of Halu Oleo, Kendari, Indonesia \\ Kartini, Darwis, Syamsuddin \\ University of Hasanuddin, Makassar, Indonesia \\ *E-mail: santiadji@uho.ac.id
}

\begin{abstract}
This study aims to find out the influence of internal control and individual morality on the prevention of fraud on PT. Regional Development Bank of Southeast Sulawesi. The population in this research is all employees of PT. Southeast Sulawesi Regional Development Bank as many as 55 employees and sampling techniques, namely saturated sampling. The results showed that partial internal control has a cynical effect on the prevention of fraud, individual morality has a significant effect on the prevention of fraud and simultaneously free variables, i.e. internal control and individual morality have a significant influence on the prevention of fraud in PT. Regional Development Bank of Southeast Sulawesi. The coefficient test of determination shows the value of $R$ Square of 0.838 this indicates that the ability of dependent variables is able to explain the variable dependency with a coefficient of determination of $83.8 \%$ while the remaining $16.2 \%$ is explained by other variables that are not studied. This indicates that the better internal control and individual morality applied, the risk of fraud will be small.
\end{abstract}

\section{KEY WORDS}

Internal control, individual morality, fraud prevention.

Indonesia's growing banking institutions make banking an important component of today's economy. The rapid development of banking institutions has an increasing risk of public confidence in vulnerable banking institutions in maintaining the level of bank health. With the widespread and large number of banking institutions, supervision of banks is needed in order to form a good banking system in order to achieve financially sound banks, managed well and professionally in order to avoid the risk of fraud. Fraud that occurs in banks is called fraud banking. Banking crime (fraud banking) is a crime committed related to the banking industry both institutions, devices and banking products, which can involve the banking and its customers, both as perpetrators and as victims.

Minimizing cheating can be done by knowing what factors are causing the cheating. According to Tuanakotta (2014) there are three factors that influence the occurrence of fraud commonly called triangel fraud or triangle fraud, namely the opportunity, pressure and rationalization. The implementation of internal controls that are not maximal provides a chance of irregularity cases. The company's weak internal control system will be one of the trigger factors that can lead to the emergence of fraud in the corporate environment. Therefore, supervision is required by management in the application of good internal controls so that the cheating can be minimized.

In albrecht research (2014) replaced rationalization factor with personal integrity or personal integrity to make it easier to observe. Personal integrity relates to each individual's personal code of conduct. Each individual's personal code of conduct refers to the level of individual moral reasoning. If a person has high moral reasoning then he will be less likely to commit fraud. Moral considerations are important for all professions in carrying out their activities, because the current problems are largely influenced by the problem of 
deterioration of moral standards and ethical crises in various professions including in the field of banking.

The profession in the banking sector in Indonesia has experienced a decline in public trust due to numerous cases of violations including the lack of morality of individual employees. The last three (3) years of 2017-2019 cases at the Regional Development Bank of Southeast Sulawesi amounted to 16 cases, indicating that the implementation of internal control in PT. The Regional Development Bank of Southeast Sulawesi is still not effective.

In addition, cheating is not only caused by the lack of implementation of internal controls but could be caused by the low individual morality of PT employees. Regional Development Bank of Southeast Sulawesi. This is due to the lack of training to instill in employees an anti-fraud attitude. Based on the background above, can be drawn some problem formulations, namely: 1) Does internal control have a significant effect on the prevention of fraud? 2) Does individual morality have a significant effect on the prevention of fraud? 3) Does internal control and individual morality have a significant effect on the prevention of fraud?

The objectives in this study are: 1) To know and analyze the influence of internal control on fraud prevention, 2) To know and analyze the influence of individual moralities on fraud prevention, 3) To know and analyze the influence of internal control and individual morality on fraud prevention.

\section{HYPOTHESIS DEVELOPMENT}

According to the Committee Of Sponsoring Organization Of The Tread way Commission (COSO) (2013) internal control is an activity designed by management and carried out by personnel at all levels of the organization to achieve the main objectives and objectives of the organization by ensuring the efficiency and effectiveness of the operating process, reliability of financial records and compliance with applicable regulations.

There are three general objectives of the company related to internal control system according to Elder, Randal J. et al. (2012) as follows:

- Organizational Efficiency and Effectiveness;

- Reliability of Financial Statements;

- Compliance with Laws and Regulations.

There are five components of the framework and are indicators of internal control of COSO according to Elder, Randal J. et al., (2012) namely:

- Environmental Control. The control environment consists of policies, actions and procedures that describe the attitude of the peak components of the entity both management, directors and owners of such entities with regard to the importance of internal control within the entity;

- Risk Assessment. Risk assessment is the process of analysis and identification carried out by management on the relevant risks in the preparation of financial statements so that the information produced in accordance with PABU;

- Control Activities. Control activities are useful to help reassure management that precautions have been taken to address risks that impede the achievement of the organization's goals;

- Information and Communication. The establishment of an accounting information and communication system by an entity aims to initiate record, process and report transactions that occur in its operational activities and to maintain accountability of related assets;

- Monitoring. Monitoring is carried out to assess the activities that are running and carried out periodically in connection with the internal control system that has been implemented by management, whether it has run in accordance with the objectives or not.

Individual morality is the ability of a person's moral reasoning to be able to decide a problem in a situation of ethical dilemma by conducting an advance assessment of the value and social of what actions will be done ethically or not. 
According to Kohlberg (1971) the stage of moral development is a measure of a person's moral highness based on the development of his moral reasoning. There are three stages of moral development, namely preconventional stages, conventional stages and postconventional stages.

There are five constructs or indicators of morals reflected in the MES according to (Nugroho, 2017) are:

- Justice atau moral equity. This construct states that doing the right thing is determined by the principle of moral justice;

- Relativism. This construct is a model of pragmatic reasoning that assumes that ethics and values are general but tied to culture;

- Egoism. This construct states that the individual always strives to maximize the welfare of the individual and considers an action is ethical if it gives an advantage to one's own;

- Utilitarianism. In this construct is reflected certain actions of a person whether it produces a large or small benefit and such actions minimize losses or maximize profits;

- Deontology/contractual. This construct is a way of reasoning by using logic to identify the task or responsibility to be performed.

Fraud is any act of dishonesty that is intentional to deprive the rights or ownership of another person or party. Tuanakotta (2014) explained that there is a triangel fraud that contains three conditions that cause fraud.

- Pressure, namely the incentive / pressure / need to commit fraud;

- Opportunity, which is a situation that opens an opportunity to allow fraud;

- Rationalization, i.e. the existence of attitudes, characters or a set of ethical values that allow certain parties to commit acts of fraud.

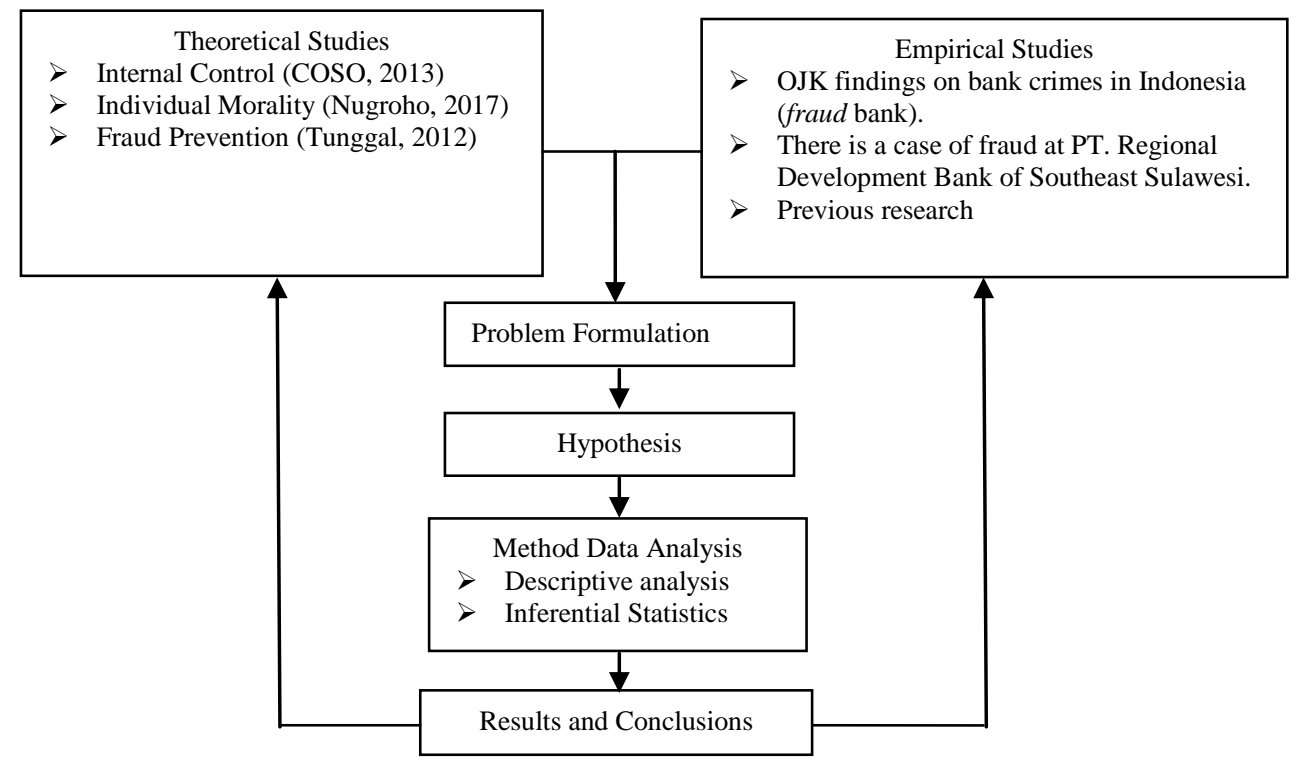

Figure 1 - Framework of study

Fraud prevention is a variety of efforts made to combat fraud that includes policies, procedures, systems, training, awareness and communication that can inhibit the occurrence of fraud so that it must be supported by all organization actors. Tunggal (2012) stated that there are several ways to prevent fraud, which then become indicators of fraud prevention including as follows:

- Honest culture and high ethics. Research shows that the most effective way to prevent and deter fraud is to implement anti-fraud programs and controls, which are based on the core values embraced by the company; 
- Management's responsibility to evaluate fraud prevention. Management is responsible for identifying and then taking identified steps to prevent fraud as well as monitor internal controls;

- Supervision by the audit committee. The audit committee assumes the primary responsibility of overseeing financial reporting as well as the organization's internal control process.

The hypotheses in this study are as follows:

- $\mathrm{H}_{1}$ : Internal control has a significant effect on the prevention of fraud;

- $\mathrm{H}_{2}$ : Individual morality has a significant effect on the prevention of fraud;

- $\mathrm{H}_{3}$ : Internal control and individual morality have a significant effect on the prevention of fraud.

\section{METHODS OF RESEARCH}

Research location of PT. The Regional Development Bank of Southeast Sulawesi is located at Jalan Mayjen Soetoyo No. 95 Kota Kendari, Southeast Sulawesi. The object in this study is the influence of internal control and individual morality as an independent variable on the prevention of fraud as a dependent variable. The population in this study is all employees who work at PT. Regional Development Bank of Southeast Sulawesi with 55 employees. The sampling technique in this study uses saturated sampling technique or often called census method, where all populations are used as analysis unit. The reason for using this method is because the population is very limited. The number of samples in the study was 55 people.

The types of data used in this research are qualitative and quantitative. Qualitative data in the form of explanations of variables and also statements in the questionnaire will be diklasifikan into categories using the likert scale. Quantitative data in this study were respondents' answers to questionnaire questions measured using scores from the likert scale.

The data sources in this study are primary data and secondary data. The primary data used in this study was the result of a questionnaire. Secondary data in the form of profile and organizational structure of PT. Regional Development Bank of Southeast Sulawesi, the findings of fraud cases at PT. Regional Development Bank of Southeast Sulawesi in 20172019.

The methods used for data collection in research are questionnaires, interviews and documentation. Questionnaires are made based on indicators, see previous research as a reference and adjust to the state of the research object. The value of the questionnaire answer was submitted in the form of modification of likert scale with the value of approval to the statement namely: SS (strongly agreed) $=5, S$ (agree) $=4, N$ (neutral) $=3$, TS (disagree) $=2$, STS (strongly disagree) $=1$. The analysis method used in this study is descriptive analysis method and inferential analysis method. Based on the relationship between internal control variables $(\mathrm{X} 1)$, individual morality $(\mathrm{X} 2)$ and fraud prevention $(\mathrm{Y})$, the linear regression analysis model is used as follows:

$$
Y=a 0+b 1 \times 1+b 2 \times 2+\varepsilon
$$

Where: $\mathrm{Y}=$ Tendency to Cheat Accounting; $\mathrm{a} 0=$ Constant; $\mathrm{b} 1, \mathrm{~b} 2=$ Regression Coefficient Of Independent Variables; X1 = Internal Control; X2 = Individual Morality; $\varepsilon=$ Epsilon (model mis-use value).

\section{RESULTS OF STUDY}

The independent variable in this study was internal control (X1) measured using 14 item questions from 5 indicators. The percentage of tendency to score answers for internal control variable statements is 4.20 which is in the good category. Individual morality variables (X2) are measured using 10 question items from 5 indicators. The percentage of tendency to score answers for individual morality 4.10 is in a good category. Fraud prevention dependent 
variable $(\mathrm{Y})$ as measured by using 9 item statement items from 3 indicators. The percentage of tendency to score answers for the 4.17 fraud prevention variable statement is in the good category.

Furthermore, data quality test was conducted on the questionnaire used. Based on validity test results and reliability test obtained that the whole item and indicators of this study showed valid and reliable results. This decision was taken because the pearson correlation value $>0.30$ with a significance level of $<0.05$ and the correlation coefficient value of the cronbach alpha $>0.60$.

The data from this study was processed using multiple regresslinear methods with the help of IBMspss 22. This is done to find out if there is an influence of internal control variables and individual morality on the prevention of fraud and from the results of processing obtained value as stated in the table as follows:

Table 1 - Linear Estimation Results Multiple Internal Control and Individual Morality Against Fraud Prevention

\begin{tabular}{|l|l|l|l|l|l|}
\hline \multirow{2}{*}{ Model } & \multicolumn{2}{|l|}{ Unstandardized Coefficients } & Standardized Coefficients & T & Sig. \\
\cline { 2 - 6 } & B & Std. Error & Beta & .828 & .412 \\
\hline (Constant) & 201 & .243 & & 5.240 & .000 \\
\hline Pengendalian & 560 & .107 & .552 & 3.793 & .000 \\
\hline Moralitas & 396 & .104 & 400 & 5 \\
\hline
\end{tabular}

Source: Processed Primary Data, 2019.

Based on the results of the regression coefficient in the table above, the equation can be obtained as follows:

$$
Y=201+0.560 X_{1}+0.396 X_{2}+\varepsilon
$$

The regression coefficient for internal control variables is 0.560 times, it can be interpreted that there is a positive influence between internal control on fraud prevention. So if the internal control variable increases by one unit and the other free variable is assumed to be constant or equal to zero, then the variable tied to fraud prevention will increase by 0.560 or $56 \%$.

The regression coefficient for morality variables is 0.396 times, meaning that there is a positive influence between individual morality on the prevention of fraud. So if the individual morality variable increases by one unit and the other free variable is assumed to be constant or equal to zero, then the variable tied to fraud prevention will increase by 0.396 or $39.6 \%$.

Internal control variables and individual morality partially and simultaneously have a significant effect on the prevention of fraud, can be known by using t-test and $\mathrm{F}_{\text {-test }} \mathrm{T}_{\text {-test }}$ summary, $\mathrm{F}_{\text {-test }}$ and determination coefficient are presented in the following table:

Table 2 - Summary of t Test, F Test and Determination Coefficient

\begin{tabular}{|l|l|l|l|l|l|l|l|}
\hline Variable & $\mathrm{t}$-hitung & $\mathrm{t}$-tabel & sig. & $\mathrm{F}_{\text {-hitung }}$ & $\mathrm{F}_{\text {-tabel }}$ & sig. & R. Square \\
\hline $\mathrm{X} 1$ & 5.240 & 1.674 & 0.000 & \multirow{2}{*}{134.619} & 2.78 & \multirow{2}{*}{$0.000^{\mathrm{b}}$} & \multirow{2}{*}{0.838} \\
\hline $\mathrm{X} 2$ & 3.793 & 1.674 & 0.000 & & & \\
\hline
\end{tabular}

Source: Data Primer, 2019.

Hypothesis testing can be done by comparing $t_{-}$count with $t_{-}{ }_{\text {table }}$ and $t_{-}$sig value with $\alpha$ : 0.05. If $\mathrm{t}_{\text {count }}>\mathrm{t}^{\mathrm{t}}$ table $_{\text {or }} \mathrm{t}_{\text {sig }}<$ from $\alpha: 0.05$ then received $\mathrm{H} 1$ or reject $\mathrm{H}_{0}$. On the contrary< if $\mathrm{t}-$ count $<\mathrm{t}^{-}$table or $\mathrm{t}_{-}$sig $>$of $\alpha$ : 0.05 then reject $\mathrm{H} 1$ or receive $\mathrm{H}_{0}$.

$\mathrm{H} 1$ : There is a significant influence of internal controls on the prevention of fraud. The

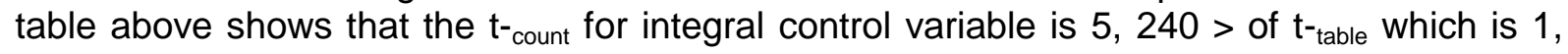
674 or with significance of $0.000<$ of $\alpha=0.050$, therefore from the test result can be concluded that $\mathrm{H} 1$ received or $\mathrm{H} 0$ rejected. This suggests that partial internal controls have a significant effect on fraud prevention. 
$\mathrm{H} 2$ : There is a significant influence of individual morality on the prevention of fraud. The table above shows that the $t_{\text {-count }}$ is $3,793>$ of the $t_{\text {-table }}$ of 1,674 amounting to or with a significance level of $0.000<$ from $\alpha=0.050$, therefore from the test results can be concluded that $\mathrm{H} 2$ received or $\mathrm{H}_{0}$ rejected. This suggests that individual morality partially affects the prevention of fraud.

The $\mathrm{F}$ test is intended to test the overall effect of a free variable on its bound variables. $\mathrm{F}$ test can be done by comparing $\mathrm{F}$-calculated value with $\mathrm{F}_{\text {-table }}$ with $<$ significance of $\alpha=$ 0.05. if $F$-calculated value $>$ of $F_{\text {-table }}$ or F-sig $<$ of $\alpha=0.05$ then $\mathrm{H}_{0}$ is rejected.

$\mathrm{H} 3$ : There is a simultaneous influence of internal control and morality of individuals on the prevention of fraud. The table above obtained F-calculated value of 134,619> from the Ftable value of 2.78 or with a significance of $F$ of $0.000<$ from $\alpha=0.050$, it can be concluded that $\mathrm{H} 3$ is accepted. This means that all free variables i.e. internal control and individual morality have a significant effect on the prevention of fraud.

The coefficient of determination is intended to determine the amount of contribution of internal control and individual morality to the prevention of fraud, by looking at the value of the coefficient of determination $\left(R^{2}\right)$. Based on table 2 known the amount of $R^{2}(R$-square $)=$ 0.838 This indicates that the direct influence of internal control variables (X1) and individual morality $(\mathrm{X} 2)$ on fraud prevention $(\mathrm{Y})$ is $83.8 \%$. This means that there is another variable or epselon variable $(16.2 \%$ that affects the $\mathrm{Y}$ variable but is not measured in this study.

\section{DISCUSSION OF RESULTS}

The effect of internal control on fraud prevention can be known by statistical testing. Partial testing is carried out to determine the effect of internal control variables on fraud prevention on PT. Regional Development Bank of Southeast Sulawesi. Based on the results of regression analysis that tested the hypothesis showed the value of $t$ calculate greater than $t$ table with sigifikansi level so that it can be concluded the results of this study showed that internal control has a significant effect on the prevention of fraud. That is, it indicates that the better internal control in PT. Regional Development Bank of Southeast Sulawesi, the risk of fraud is getting smaller.

Environmental control at PT. The Regional Development Bank of Southeast Sulawesi has been very good. This can be seen from the average respondent's answer to this item is very well categorized. This means that, the majority of employees at PT. The Southeast Sulawesi Regional Development Bank in terms of conducive control environment is formed by management and employees who have a commitment and a positive attitude towards internal control and have also held firm to the principle that control is very important so that this will affect the prevention of fraud.

Estimating the risks that exist in PT. The Regional Development Bank of Southeast Sulawesi has an influence on the prevention of fraud. This can be seen from the average respondent's answer on this item which is well categorized. This means that, the majority of employees at PT. The Regional Development Bank of Southeast Sulawesi assesses the risks as part of the design system with the aim of avoiding indications of fraud. This will have an effect on the prevention of cheating.

Control activities at PT. The Regional Development Bank of Southeast Sulawesi is already running well. This can be seen from the average respondent's answer on this item which is well categorized. This means that, the majority of employees at PT. The Regional Development Bank of Southeast Sulawesi always tries to take fraud prevention measures to overcome the risks that hinder the achievement of the organization's objectives. This will have an effect on the prevention of cheating.

Information and communication at PT. The Regional Development Bank of Southeast Sulawesi is already running very well. This can be seen from the average answer of respondents on this item who are in the category very well. This means that the attitude of management in running and controlling operations at PT. The Regional Development Bank of Southeast Sulawesi has communicated relevant, reliable and timely events. So this will affect the prevention of cheating. 
Monitoring on PT. The Regional Development Bank of Southeast Sulawesi is already running very well. This can be seen from the average answer of respondents on this item who are in the category very well. This means that, the majority of employees at PT. The Regional Development Bank of Southeast Sulawesi feels that it has been able to provide adequate monitoring in preventing indications of fraud. This will have an effect on the prevention of cheating.

The results showed that internal control in PT. Regional Development Bank of Southeast Sulawesi whose indicators consist of environmental control, risk assessment, information and communication, control activities and monitoring support to prevent fraud. Where cheating is influenced by several factors such as pressure, opportunity and rationalization. The better the internal investigation applied to PT. Regional Development Bank of Southeast Sulawesi, the risk of fraud is getting smaller.

These results support from a specific, more specific understanding of internal controls to prevent fraud according to the Committee of Sonsoring Organizations of the Treadway Commission (2013) as a system containing processes and procedures with specific objectives designed and implemented to achieve the main objective of preventing fraud.

The results of this study are in line with Sukadwilinda's research, R Aryanti Ratnawati (2013) which stated that internal control has a significant influence on the prevention of fraud. With this indicates that the better the internal control, the less risk of fraud.

The influence of individual morality on the prevention of cheating can be known by statistical testing. Partial testing is carried out to determine the effect of individual morality variables on fraud prevention on PT. Regional Development Bank of Southeast Sulawesi. Based on the results of regression analysis that tested the hypothesis showed the value of $t$ calculate greater than $t$ table with a smaller level of significance, so it can be concluded that the results of this study showed that individual morality has a significant influence on the prevention of cheating. This means that, the ability of a person's moral reasoning to be able to decide problems when facing ethical dilemmas by conducting an advance assessment of the value and social of fulfilling the actions he will do ethically or unethically, so that the risk of fraud is less.

Justice or moral equity of PT employees. The Regional Development Bank of Southeast Sulawesi has been good. This can be seen from the average score of respondents' responses to this item which is in a good category. Giving the meaning that, the majority of pt employees. The Regional Development Bank of Southeast Sulawesi, when faced with a situation of ethical dilemmas, felt able to do something morally right. This reduces the risk of fraud.

Relativism employees of PT. The Regional Development Bank of Southeast Sulawesi has been good. This can be seen from the average score of respondents' responses to this item which is in a good category. Giving the meaning that, the majority of pt employees. The Regional Development Bank of Southeast Sulawesi, when faced with a situation of ethical dilemmas, feels able to take actions that are culturally and traditionally acceptable. This reduces the risk of fraud.

Egoism employees of PT. The Regional Development Bank of Southeast Sulawesi has been good. This can be seen from the average score of respondents' responses to this item which is in a good category. Giving the meaning that, the majority of pt employees. The Regional Development Bank of Southeast Sulawesi, when faced with an ethical dilemma, feels able to take actions that maximize its welfare by considering its moral reasoning which is the process of determining right or wrong in making an ethical decision. This reduces the risk of fraud.

Utilitarianism employees of PT. The Regional Development Bank of Southeast Sulawesi has been good. This can be seen from the average score of respondents' responses to this item which is in a good category. Giving the meaning that, the majority of pt employees. The Regional Development Bank of Southeast Sulawesi, when faced with an ethical dilemma, felt able to take actions that could maximize profits and minimize the company's losses so that this would reduce the risk of fraud. 
Deontology/contractual employees of PT. The Regional Development Bank of Southeast Sulawesi has been good. This can be seen from the average score of respondents' responses to this item which is in a good category. Giving the meaning that, the majority of pt employees. The Regional Development Bank of Southeast Sulawesi, when faced with an ethical dilemma situation, feels that it is able to hold firm not to commit violations of oaths of office or written contracts, so that this will reduce the risk of theft.

The results showed that the morality of individuals in PT. Regional Development Bank of Southeast Sulawesi whose indicators consist of justice or moral equity, relativism, egoism, utlitarianism and deontology / contractual support to prevent fraud where cheating is a deliberate dishonesty to deprive the rights of others. The better the individual morality applied by each employee masimg PT. Regional Development Bank of Southeast Sulawesi, the risk of fraud is getting smaller.

These results support Kohlberg's theory (1971) that individual morality is the ability of one's moral reasoning to be able to decide a problem in a situation of ethical dilemma by conducting an advance assessment of the value and social of what actions will be done ethically or not.

The results of this study are in line with the research of Fajar Qoirul Nugroho (2017) which states that individual morality has an influential and significant effect on the prevention of fraud. With this indicates that when the morality of an individual built by an employee is good in the sense of reasoning morality is high then it will reduce the risk of fraud.

Hypothetical test results show that internal control variables and individual morality simultaneously have a significant effect on the prevention of fraud. Such influence can be seen from the value of $\mathrm{F}$ calculate greater than $\mathrm{F}$ table with a smaller level of significance, so it can be concluded that internal control and morality of individuals have a significant influence on the prevention of fraud. This indicates that the better the internal control in PT. Regional Development Bank of Southeast Sulawesi, the risk of fraud will be smaller. The better the individual morality of the PT. Regional Development Bank of Southeast Sulawesi, the risk of fraud is getting smaller.

Good internal control and individual morality will reduce the risk of fraud. The most influential indicators on fraud prevention variables are honest culture and high ethics. It can be explained that the culture of honesty and high ethics built by employees at PT. The Regional Development Bank of Southeast Sulawesi has been very good. This can be seen from the average respondent's answer to this item which is in the category very well. This means that, the majority of PT employees. The Regional Development Bank of Southeast Sulawesi has been able to implement anti-fraud programs and controls based on core values embraced by the company very well. The values in question are to create an environment that supports acceptable behavior and expectations that employees can use value to direct their actions. So this will reduce the risk of fraud. Management's responsibility to evaluate fraud prevention at PT. The Regional Development Bank of Southeast Sulawesi can be said to be very good. This can be seen from the average respondent's answer to this item which is in the excellent category. That is, management at PT. The Regional Development Bank of Southeast Sulawesi is responsible for taking identified measures to monitor internal controls that prevent and identify fraud. so that this will reduce the risk of fraud.

Supervision by the audit committee at PT. The Regional Development Bank of Southeast Sulawesi can be said to be good. This can be seen from the average respondent's answer to this item which is in a good category. That is, the audit committee at PT. The Regional Development Bank of Southeast Sulawesi is able to take into account the potential for neglect of internal control by management, supervise the process of fraud prevention by management and help create an effective tone at the top on the importance of honesty and ethical behavior by supporting management's zero tolerance against fraud. So this will reduce the risk of fraud.

The results showed that the prevention of cheating in PT. The Southeast Sulawesi Regional Development Bank, whose indicators consist of a culture of honesty and high ethics, management responsibilities and supervision of the audit committee, supports to prevent fraud. The results of this study are in line with research conducted by Dionisia Nadya 
Sri Damayanti (2016), and Nur Khasanah Sahidin (2018) which stated that effective internal control and high individual morality have a significant influence on the prevention of fraud. This means that, the better the internal control and morality of the individual applied, the risk of fraud will be less.

\section{CONCLUSION}

Conclusion of Research at PT Bank Pembangunan Daerah Sulawesi Tenggara by looking at the influence of internal control and individual morality on fraud prevention as follows: (1) Internal control has a significant influence on the prevention of fraud, (2) Individual morality has a significant influence on the prevention of fraud, (3) Internal control and individual morality have a significant effect on the prevention of fraud.

\section{REFERENCES}

1. Agoes, Soekrisno. 2012. Auditing. Buku satu. Jakarta: Salemba empat.

2. Albrecht, W. Steve. 2014. "Iconic Fraud Triangle Endures". Fraud Magazine. Association of Certified Fraud Examiners, Inc.

3. Bank Indonesia, "Surat Edaran Bank Indonesia No 13/28/Dpnp/ Tanggal 9 Desember 2011 Perihal Penerapan Strategi Anti Fraud Pada Bank Umum". Angka 1 Butir 2.

4. Committe Of Sponsoring Organizations Of The Treadway Comission (COSO).2013. "2013 Coso Framework". https://auditinternalindonesi a.wordpress.com/2014/10/12/slideippf-dan-coso-2013/. Diakses 5 November 2018.

5. Damayanti, Dionisia Nadya Sri. 2016. "Pengaruh Pengendalian Internal and Moralitas Individu Terhadp Kecurangan Akuntansi”. Skripsi. Universitas Yogyakarta.

6. Ikatan Akuntan Indonesia IAI (IAI). (2001). "Pengendalian Intern Dalam Audit Laporan Keuangan “. Standar Audit Seksi 319 (PSA No. 69).

7. Kohlberg, Lawrence. 1971. "Stages of Moral Development". Diakses melalui http://info.psu.edu.sa/psu/maths/stages of Moral Development According Kohlberg. pdf pada tanggal 16 November 2016.

8. Liyanarchi, G. 2009. The Impact of Moral Reasoning and Retaliation on Whitsle Blowing: New-Zealand Evidence. Journal Of Business Ethics 89.

9. Mulyadi. 2009. Auditing. Buku Satu. Jakarta: Salemba Empat.

10. Nugroho, Fajar Qoirul. 2017. "Pengaruh Moralitas Individu and Idealisme Terhadap Persepsi Etis Mahasiswa Akuntansi Mengenai Praktik Akuntansi Kreatif Di Perusahaan Dengan Tingkat Pemahaman Kode Etik Akuntan Sebagai Variabel Moderasi: Studi Pada Mahasiswa Prodi Akuntansi Universitas Negeri”. Skripsi. Uiversitas Negeri Yogyakarta.

11. Otoritas Jasa Keuangan (OJK). (2017). “126 kasus Tipibank 2014-2017”.Diaksesmelalui https://ekbis.sindonews.com-perbankan pada tanggal 4 Mei 2017.

12. Ratnawati, Sukadwilinda R Aryanti. 2013. Pengaruh Pengendalian Internal Terhadap Pencegahan Kecurangan (Fraud) Kas: Studi pada PT. Bank Mandiri (Persero) Tbk, Area Asia Afrika Bandung".Jurnal Aset (Akuntansi Riset). Fakultas Ekonomi Universitas Sangga Buana Jawa Barat, Indonesia.

13. Sahidin, Nur Khasanah. 2018. "Pengaruh Pengendalian Internal and Ethical Judgment Terhadap Pencegahan Kecurangan: Studi pada PT. Pelindo IV Sulawesi Selatan". Journal SNA XXI Fakultas Ekonomi Universitas Hasanuddin.

14. Sugiyono_.2017. Metode Peneitian Kuantitatif Kualitatif and R \& D. Bandung: Alfabeta.

15. Tarigan, Laurensia Br. 2016. Pengaruh Moralitasindividu, Asimetri Informasi Efektivitas Pengendalian Internal and Ketaatan Aturan Akuntansi Terhadap Kecenderungan Kecurangan Akuntansi. Riau. Journal Fakultas Ekonomi Universitas Riau.

16. Tuanakotta, Theodorus M. 2012. Akuntansi Forensik and Audit Investlgatif. Jakarta.

17. Tunggal, Amin Widjaja. 2012. Audit Kecurangan and Akuntansi Forensik. Jakarta.

18. Wilopo. 2006. Analisis Faktor-Faktor Yang Berpengaruh Terhadap Kecenderungan Kecurangan Akuntansi: Studi Pada Perusahaan Publik and Badan Usaha Milik Negara di Indoneia. Simposium Nasional Akuntansi IX: Padang. 23-26 Agustus 2006. 